\title{
Studies on the Coumarin Anticoagulant Drugs: Interaction of Human Plasma Albumin and Warfarin Sodium*
}

\author{
ROBERT A. O'REILly $†$ WITH THE TECH NICAL ASSISTANCE OF \\ Patricia E. Kowitz \\ (From the Departments of Medicine, Santa Clara Valley Medical Center, San Jose, and the \\ University of California School of Medicine, San Francisco, and the Institute for \\ Medical Research of Santa Clara County, San Jose, Calif.)
}

Summary. In studies by continuous flow electrophoresis the coumarin anticoagulant drug warfarin sodium was found to be bound solely to the albumin fraction of the plasma proteins. The interaction was studied in detail by equilibrium dialysis of solutions of crystalline human plasma albumin and warfarin sodium. Analysis of the data showed that albumin possesses a single strong binding site for warfarin with an association constant of 154,000 at $3^{\circ} \mathrm{C}$ and secondary classes of several sites with a much lower affinity. The free energy of binding for the first anion determined at $3^{\circ}$ and $37^{\circ} \mathrm{C}$ was -6.54 and $-7.01 \mathrm{kcal}$ per mole, respectively. The standard enthalpy change for the interaction was $-3.48 \mathrm{kcal}$ per mole, and the entropy change was $+11.2 \mathrm{U}$.

The negative enthalpy change was surprisingly large and the positive entropy change small for an anion-albumin interaction, suggesting significant nonionic binding. The inability to saturate the albumin binding sites, even when high concentrations of warfarin were used, is consistent with a reversible configurational alteration of the albumin molecule during the binding process. The thermodynamic data indicate that the albumin binding sites for warfarin sodium are formed during the process of binding, rather than being preformed as in antigen-antibody reactions. The strength of the binding process suggests that many of the pharmacodynamic characteristics of warfarin sodium in man are determined by its strong interaction with plasma albumin. Such correlations of the physicochemical interactions and biologic effects of the coumarin anticoagulant drugs should lead to a better understanding of their mechanisms of action.

\section{Introduction}

In previous studies of the pharmacodynamics of the coumarin anticoagulant drug warfarin sodium in man (1), the drug was found to be almost wholly bound to the plasma proteins. When normal human plasma containing ${ }^{14} \mathrm{C}$-labeled war-

\footnotetext{
* Submitted for publication October 3, 1966; accepted January 27, 1967.

Supported by grant HE-8058-04 from the National Institutes of Health.

$\dagger$ Address requests for reprints to Dr. Robert A. O'Reilly, Dept. of Medicine, Santa Clara Valley Medical Center, San Jose, Calif. 95128.
}

farin was subjected to paper electrophoresis, the radioactivity appeared to be confined to the albumin band. These studies, however, left two unresolved problems. First, because of the limited capacity of the electrophoretic system and the relatively low specific activity of warfarin, significant binding to the faster moving globulin fractions could not be ruled out. Second, many of the pharmacodynamic findings could be explained only if the interaction between warfarin and the plasma proteins were strong.

In the present investigation both in vitro and in vivo binding of warfarin sodium was deter- 
mined by continuous flow electrophoresis. The finding that warfarin was bound exclusively to the plasma albumin fraction led to further study of the binding process. The recent availability of crystalline preparations of human plasma albumin and warfarin sodium made it possible to examine their interaction by equilibrium dialysis. The results obtained in these experiments allowed calculation of the binding strength, the number and classes of binding sites, the free energy of binding, and the standard enthalpy and entropy changes. Based on these data, hypotheses are presented for the molecular basis of the warfarin-albumin interaction and for the pharmacodynamic characteristics of the drug.

\section{Methods}

\section{Continuous flow electrophoresis 1}

Determination of in vitro binding of warfarin to plasma albumin. Crystalline warfarin sodium was added to pooled normal human plasma to achieve a concentration of $200 \mathrm{mg}$ per $\mathrm{ml}$. The plasma-warfarin mixture was fed to a continuous flow electrophoretic apparatus at a rate of $1.4 \mathrm{ml}$ per hour (2). It was applied to the top of the curtain about one-third of the distance from the cathode toward the anode. Electrochromatography was then carried out at $1,900 \mathrm{v}$ and $60 \mathrm{ma}$ at $2.4^{\circ} \mathrm{C}$ in 0.0065 $\mathrm{M}$ ammonium acetate buffer at $\mathrm{pH} 6.9$ for $2 \frac{1}{2}$ hours. A total of $3.5 \mathrm{ml}$ of plasma was used. Thirty-one fractions were collected in tubes at the bottom of the curtain. Each fraction was divided in half. One half was subjected to cellulose acetate electrophoresis and stained for protein; this technique will detect as little as $0.01 \mathrm{~g}$ of protein per $100 \mathrm{ml}$. The other half was analyzed for warfarin content (3).

Determination of in vivo binding of warfarin to plasma albumin. Plasma was obtained from a subject with hereditary resistance to coumarin anticoagulant drugs (4). At the time of study, the patient was receiving a maintenance dose of $145 \mathrm{mg}$ of warfarin daily, and the concentration of warfarin in his plasma averaged $55 \mathrm{mg}$ per L. The plasma disposition of warfarin in this patient is identical to that in normal subjects, both in the form of the drug present (unchanged warfarin) and the quantity bound to protein $(97 \%)(5)$. The plasma was added to a continuous flow electrophoretic apparatus at a rate of $1.4 \mathrm{ml}$ per hour as described previously. Electrochromatography was carried out at $1,900 \mathrm{v}$ and $85 \mathrm{ma}$ at $3.2^{\circ} \mathrm{C}$ in $0.0065 \mathrm{M}$ ammonium acetate buffer at $\mathrm{pH} 6.9$. The procedure required $3 \frac{1}{2}$ hours, and a total of $4.9 \mathrm{ml}$ of plasma was used. The fractions were then collected, divided, and analyzed as before.

${ }_{1}$ Dr. Arthur Karler kindly performed the electrochromatographic studies.

\section{Equilibrium dialysis}

Methods. Human plasma albumin, 2 prepared by repeated crystallization from Cohn Fraction V, was used in all experiments. By cellulose acetate electrophoretic analysis, the albumin was $100 \%$ pure. The water content of the albumin, evaluated by heating a small sample in an oven at $110^{\circ} \mathrm{C}$ until a constant weight was obtained, was found repeatedly to be less than $1 \%$; therefore, no correction for water content was required. The albumin was prepared in phosphate buffer, 0.067 mole per $\mathrm{L}, \mathrm{pH}$ 7.4 , in concentrations ranging from 0.1 to $5 \%$.

Two forms of warfarin sodium were used: a clathrate prepared by repeated crystallization of amorphous warfarin sodium from isopropyl alcohol (91.2\% warfarin sodium), and an amorphous powder prepared by commercial methods (97.0\% warfarin sodium, with $3.15 \%$ loss on drying to a constant weight) (6)..$^{3}$ The concentration of warfarin sodium in $0.067 \mathrm{M}$ phosphate buffer, $\mathrm{pH} 7.4$, was varied over a 400 -fold range ( 6.10 to $2,420 \mu$ moles per $\mathrm{L})$. When corrected for the difference in warfarin sodium content, the results obtained with the two forms of the drug did not vary significantly.

Dialysis bags were made from Visking cellophane casing ( 15 inch). The casings were cleaned by continuous rinsing in a recycling bath of deionized water for 8 hours and could then be stored up to 10 days in deionized water at $4^{\circ} \mathrm{C}$. Just before use the bags were washed repeatedly with deionized water, followed by the phosphate buffer; they were not allowed to dry. With this technique the optical density of blank buffer carried through a run at the maximal wavelength of warfarin was always less than 0.005 .

Experimental. Ten $\mathrm{ml}$ of albumin-buffer solution was added inside the dialysis bag, and $15 \mathrm{ml}$ of warfarinbuffer solution was added outside. To ensure efficient mixing, we prepared the bags with an enclosed air bubble and without tension. Dialysis was carried out in $50-\mathrm{ml}$ glass tubes covered with Parafilm caps. The tubes were placed on a horizontal wrist-action shaker with a capacity of 24 tubes and rocked through a $5^{\circ}$ arc at a frequency at $150 \mathrm{cpm}$. All experiments were conducted at $\mathrm{pH} 7.4$ with $0.067 \mathrm{M}$ phosphate buffer; no detectable change in $\mathrm{pH}$ occurred at equilibrium. The ionic strength $(0.17)$ was high enough to render the Donnan correction negligible, since no measurable change in fluid volume inside the dialysis bag could be detected at equilibrium. Equilibrium controls, consisting of warfarin-buffer solution outside and buffer solution inside the dialysis bags, were included in all experiments. To rule out leakage of albumin, we routinely tested the fluid outside the dialysis bags with $3 \%$ sulfosalicylic acid; in no instance was protein found outside the bags. Since warfarin, like most ligands, is adsorbed to some extent by the dialysis bags, calculation of the amount of warfarin actually bound by albumin requires a correction for bag binding. To determine the de-

\footnotetext{
2 Obtained from Pentex Corp., Kankakee, Ill.

${ }^{3}$ Kindly supplied by the late Dr. Nathan Weiner, Endo Laboratories, Garden City, N. Y.
} 
gree of adsorption to the bags, we carried out dialysis as described, but without the addition of albumin.

At equilibrium, the concentration of unbound warfarin on both sides of the membrane must be equal, and any increment of the drug in the protein compartment represents bound warfarin (7). The concentration of free warfarin anion in equilibrium with bound anion was determined by measuring the drug concentration outside the dialysis bag. The method used for determining warfarin content (3) will detect concentrations as low as $5 \mu$ moles per $\mathrm{L}$ and has an error of $2 \%$. The amount of albumin-bound warfarin was determined by subtracting the free and bag-bound warfarin from the amount added initially. The accuracy of the method was verified in separate experiments with ${ }^{14} \mathrm{C}$-labeled warfarin, ${ }^{4}$ in which the labeled warfarin inside and outside the dialysis bags was determined by liquid scintillation counting. The results obtained by the two methods at all concentrations of warfarin varied less than $1 \%$. Whether the drug was added initially to the inside or outside of the dialysis bag had no effect on the percentage of warfarin bound to albumin.

To allow calculation of the thermodynamic functions of enthalpy $(\Delta \mathrm{H})$ and entropy $(\Delta \mathrm{S})$ for the binding process, we conducted all experiments at four different temperatures. Experiments at $3^{\circ}$ and $15^{\circ} \mathrm{C}$ were conducted in a cold chamber, those at $27^{\circ} \mathrm{C}$ in a temperature-controlled room, and those at $37^{\circ} \mathrm{C}$ in a constant temperature water bath. All temperatures were maintained at less than $\pm 1^{\circ} \mathrm{C}$ variation. Since equilibrium was achieved rapidly (within 3 hours at $27^{\circ}$ and $37^{\circ} \mathrm{C}$ and within 10 hours at $3^{\circ}$ and $15^{\circ} \mathrm{C}$ ), addition of preservatives or bacteriostatic agents was not required.

The binding constants for the interaction of warfarin and albumin were analyzed by means of the Scatchard equation for the law of mass action ( 7$): \bar{\nu} / \mathrm{A}=\mathrm{kn}-\mathrm{k} \bar{\nu}$ where $\bar{\nu}$ is the molar ratio of bound warfarin to albumin, $A$ is the molar concentration of free warfarin at equilibrium, $\mathrm{k}$ is the average apparent association constant for the binding at each site, and $n$ is the average maximal number of binding sites on the albumin molecule. The values of $\bar{\nu} / \mathrm{A}$ plotted against $\bar{\nu}$ give a straight line when all the binding sites are independent and equivalent. Deviations from linearity can arise from interaction of the bound anions or from the occurrence of binding at more than one class of sites with different association constants (8). As $\bar{\nu} / \mathrm{A}$ approaches zero as a limit, the intercept on the $\bar{\nu}$ axis is $\mathrm{n}$, and as $\bar{\nu}$ approaches zero as a limit, the intercept on the $\bar{\nu} / \mathrm{A}$ axis is $\mathrm{kn}$, the classical association constant for the first anion bound (9).

The standard free energy of binding $\left(\Delta \mathrm{F}^{\circ}\right)$ was determined from the association constant $(k)$ for the interaction by the general thermodynamic relationship $\Delta \mathrm{F}=-\mathrm{RT} \ln \mathrm{k}$, where $\mathrm{R}$ is the gas law constant and $\mathrm{T}$ the absolute temperature (9). The standard enthalpy change $\left(\Delta \mathrm{H}^{\circ}\right)$, or temperature-dependent portion of the

4 Kindly provided by Professor K. P. Link, University of Wisconsin School of Agriculture, and Dr. C. Schroeder, Wisconsin Alumni Research Foundation.

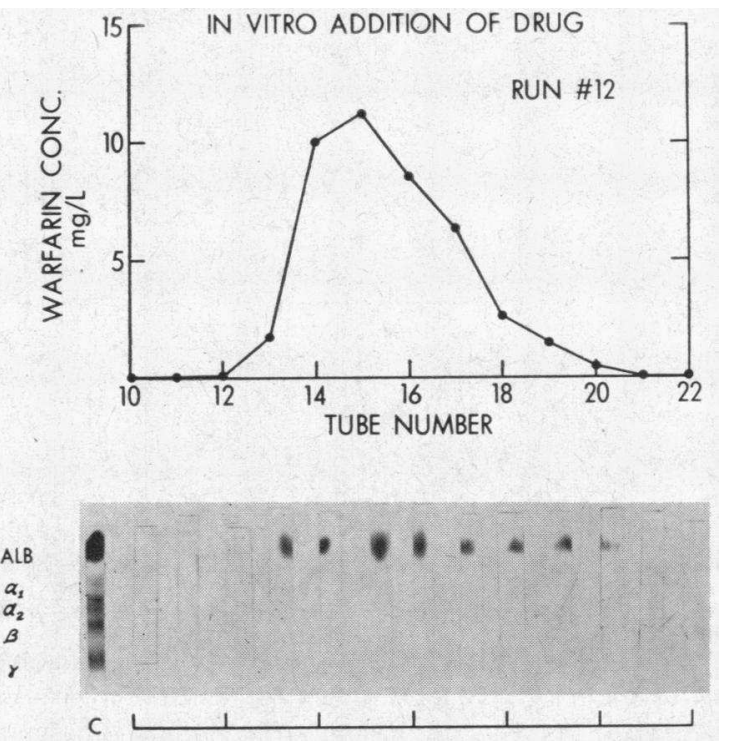

Fig. 1. Electrochromatographic Studies: in vitro BINDING OF WARFARIN SODIUM TO NORMAL HUMAN PLASMA ALBUMin. The warfarin concentration plotted as a function of the electrochromatographic plasma fractions expressed by tube number is shown in the upper graph. The cellulose acetate electrophoretic strips indicating the protein content of each tube fraction are shown below. $\mathrm{C}=$ control strip; $\mathrm{ALB}=$ albumin fraction.

association, was determined from a van't Hoff plot, where the logarithm of the association constant was expressed as a function of the reciprocal of the absolute temperature (10). The entropy change was determined from the thermodynamic relationship $\Delta \mathrm{F}=\Delta \mathrm{H}-\mathrm{T} \Delta \mathrm{S}$ (9).

\section{Results}

\section{Continuous flow electrophoresis}

In the in vitro binding experiments albumin was found only in collecting tubes 12 through 21 ; in tubes 12 through 20 no globulin could be detected (Figure 1). The total amount of added warfarin was contained in tubes 13 through 20 , with the highest concentrations in the tubes containing the highest concentrations of albumin. No warfarin was detected in the tubes that did not contain albumin.

In the in vivo binding experiments albumin was found only in collecting tubes 10 through 16; no globulin could be detected in any of these tubes (Figure 2). Warfarin was found only in tubes 11 through 16 and was in direct proportion to the amount of albumin present. Thus, in both 

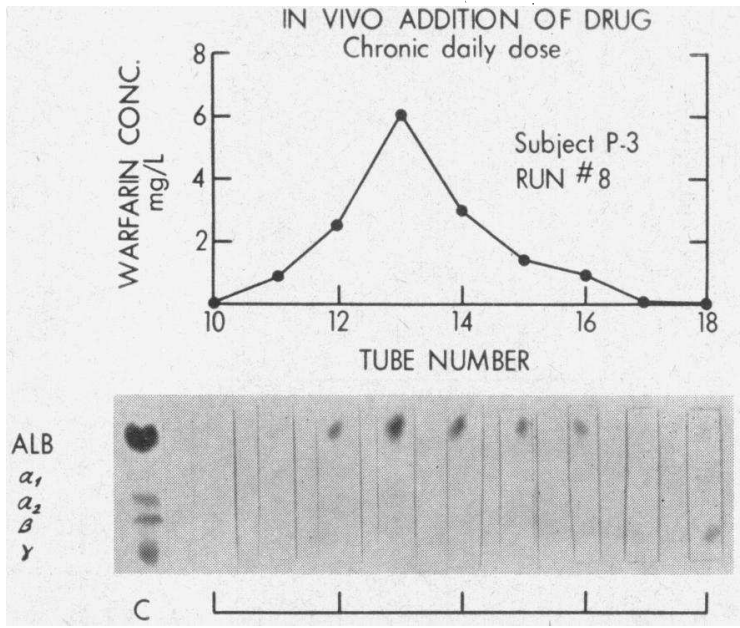

Fig. 2. Electrochromatographic STUdIES: IN vivo BINDING OF WARFARIN SODIUM TO NORMAL HUMAN PLASMA ALBUMIN. The warfarin concentration plotted as a function of the electrochromatographic plasma fractions expressed by tube number is shown in the upper graph. The cellulose acetate electrophoretic strips indicating the protein content of each tube fraction are shown below.

in vitro and in vivo binding experiments the warfarin was bound exclusively to the albumin fraction.

\section{Equilibrium dialysis}

Preliminary studies. A series of experiments was carried out to determine $a$ ) the effect of different concentrations of protein and warfarin on the extent of binding, and $b$ ) the degree of adsorption of warfarin to the dialysis bags. When a warfarin concentration of $100 \mathrm{mg}$ per L (303 $\mu$ moles per L) was used and the albumin concentration was varied from 0.1 to $5 \%$ ( 14.5 to 724 $\mu$ moles per L), the percentage of bound warfarin rose from 13 to $95 \%$ (Figure 3 ). When the albumin concentration was kept at $0.4 \%$ (57.9 $\mu$ moles per $L)$ and the warfarin concentration was varied from 2 to $400 \mathrm{mg}$ per L (6.1 to 1,212 $\mu$ moles per $\mathrm{L})$, the percentage of bound warfarin declined from 81 to $19 \%$, falling rapidly at lower concentrations and then more slowly at higher ones (Figure 3). These data indicate that the $0.4 \%$ concentration of albumin was suitable for studying the binding of warfarin over a wide range of concentrations. The use of a low concentration of albumin was desirable to avoid a Donnan effect and protein-protein interaction. The mo-

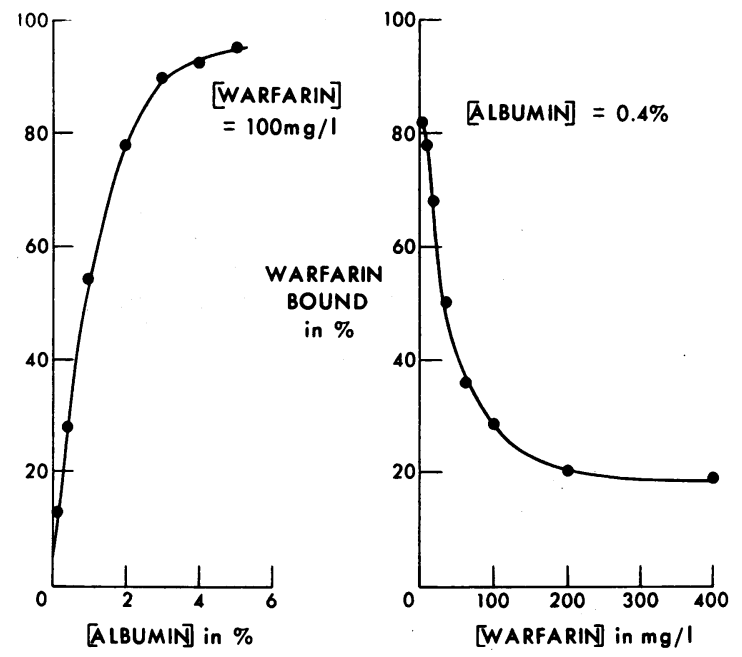

Fig. 3. EQUilibrium dialysis studies: EFFECT OF VARYING CONCENTRATIONS OF ALBUMIN AND WARFARIN ON PERCENTAGE OF DRUG BOUND. The percentage of bound warfarin is plotted as a function of the albumin concentration (left) and as a function of the warfarin concentration (right).

\section{BAG BINDING}

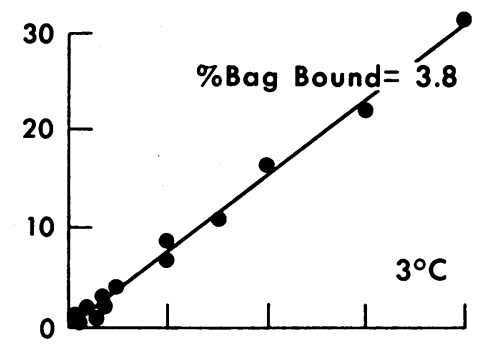

\section{BAG BOUND}

[WARFARIN], $\mathrm{mg} / \mathrm{I}$

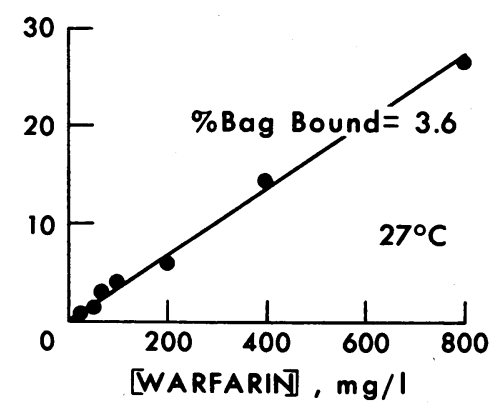

Fig. 4. EQUilibrium dialysis studies: AMOUNT OF WARFARIN ADSORBED TO DIALYSIS BAGS. The amount of warfarin bound to the dialysis bags is plotted as a function of the amount of warfarin added to the dialysis system. Determinations at $3^{\circ} \mathrm{C}$ (top) and at $27^{\circ} \mathrm{C}$ (bottom). 
lecular weight of albumin was assumed to be 69,000 (11).

To determine the degree of bag binding, we carried out the experiments with concentrations of warfarin ranging from 6 to $2,420 \mu$ moles per $\mathrm{L}$ in the absence of protein (Figure 4). A linear relationship was found between the amount of warfarin added to the dialysis system and the amount bound to the bags. The percentage of warfarin bound to the dialysis bags was $3.8 \%$ at $3^{\circ} \mathrm{C}$ and $3.6 \%$ at $27^{\circ} \mathrm{C}$.

Definitive studies. Further experiments with an albumin concentration of $0.4 \%$ and warfarin sodium concentrations ranging from 2 to $800 \mathrm{mg}$ per $\mathrm{L}$ were then carried out at $3^{\circ}, 15^{\circ}, 27^{\circ}$, and $37^{\circ}$ C. Approximately 100 experiments were done at each temperature. The results at $3^{\circ}$ and $27^{\circ} \mathrm{C}$, analyzed by means of the Scatchard equation, are plotted in Figure 5. The data follow curvilinear courses that bend sharply near the abscissa, indicating that more than one class of binding site is present (12). The reproducibility

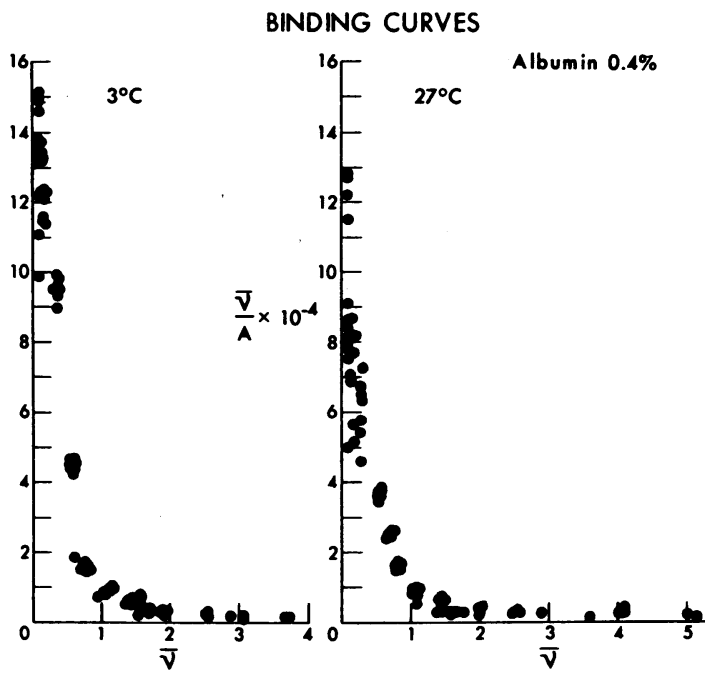

Fig. 5. EQUilibrium dialysis StUdies: SCATChard PLOTS OF DATA OBTAINED IN IN VITRO BINDING EXPERIMENTS. Results at $3^{\circ} \mathrm{C}$ (left), and $27^{\circ} \mathrm{C}$ (right). $\bar{\nu}=$ molar ratio of warfarin sodium bound to albumin; $\bar{\nu} / \mathrm{A}=\bar{\nu}$ divided by the molar concentration of free warfarin at equilibrium.

TABLE I

Mean binding data for each concentration of warfarin studied

\begin{tabular}{|c|c|c|c|c|c|c|}
\hline \multirow[b]{2}{*}{$\begin{array}{l}\text { No. of } \\
\text { experiments }\end{array}$} & \multirow[b]{2}{*}{$\begin{array}{l}\text { Initial warfarin } \\
\text { concentration }\end{array}$} & \multicolumn{3}{|c|}{ Final warfarin concentration at equilibrium } & \multirow[b]{2}{*}{$\bar{\nu} \pm \mathrm{SE} \dagger$} & \\
\hline & & $\begin{array}{c}\text { Albumin } \\
\text { bound }\end{array}$ & $\begin{array}{l}\text { Unbound } \\
(\mathrm{A})^{*}\end{array}$ & $\underset{\text { bound }}{\mathrm{Bag}}$ & & $\bar{\nu} / A \pm S E \ddagger$ \\
\hline & \multicolumn{5}{|c|}{ Mmoles $/ L$} & $L /$ moles $\times 10^{-2}$ \\
\hline $\begin{array}{r}16 \\
12 \\
12 \\
12 \\
10 \\
10 \\
10 \\
10 \\
7 \\
6\end{array}$ & $\begin{array}{r}6.1 \\
12.1 \\
24.2 \\
48.4 \\
96.9 \\
193.6 \\
303 \\
606 \\
1,212 \\
2,424\end{array}$ & $\begin{array}{r}5.2 \\
10.1 \\
19.7 \\
33.6 \\
45.1 \\
65.4 \\
82.1 \\
102.4 \\
133.1 \\
196.9\end{array}$ & $\begin{array}{r}0.7 \\
1.5 \\
3.6 \\
13.1 \\
48.1 \\
120.8 \\
209.4 \\
480.3 \\
1,032.7 \\
2,134.9\end{array}$ & $\begin{array}{r}0.2 \\
0.5 \\
0.9 \\
1.7 \\
3.7 \\
7.4 \\
11.5 \\
23.3 \\
46.2 \\
92.3\end{array}$ & 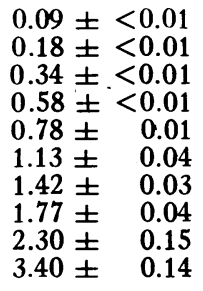 & $\begin{array}{r}130 \pm \quad 4 \\
120 \pm \quad 5 \\
94 \pm \quad 1 \\
44 \pm<1 \\
16 \pm<1 \\
9 \pm<1 \\
7 \pm<1 \\
4 \pm<1 \\
2 \pm<1 \\
1 \pm<1\end{array}$ \\
\hline \multicolumn{7}{|c|}{$27^{\circ} \mathrm{C}$} \\
\hline $\begin{array}{r}16 \\
13 \\
12 \\
10 \\
10 \\
10 \\
10 \\
12 \\
10 \\
8\end{array}$ & $\begin{array}{r}6.1 \\
12.1 \\
24.2 \\
48.4 \\
96.9 \\
193.6 \\
303 \\
606 \\
1,212 \\
2,424\end{array}$ & $\begin{array}{r}4.9 \\
9.6 \\
18.1 \\
32.1 \\
44.0 \\
64.8 \\
80.5 \\
99.6 \\
159.8 \\
242.8\end{array}$ & $\begin{array}{r}1.0 \\
2.2 \\
5.3 \\
14.7 \\
49.5 \\
121.8 \\
211.6 \\
484.6 \\
1,008.6 \\
2,094.0\end{array}$ & $\begin{array}{r}0.2 \\
0.5 \\
0.8 \\
1.6 \\
3.4 \\
7.0 \\
10.9 \\
21.8 \\
43.6 \\
87.3\end{array}$ & 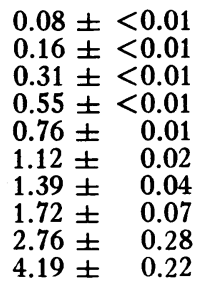 & 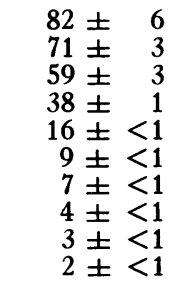 \\
\hline
\end{tabular}

* Molar concentration of free warfarin at equilibrium.

† Average molar ratio of bound warfarin to albumin, determined by dividing data in the third column by 57.9 $\mu$ moles per $\mathrm{L}$.

$\ddagger$ Calculated by dividing data of the sixth column by data of the fourth column. 
of the experiments was excellent at every concentration of warfarin used; the standard errors of the means for both $\bar{v}$ and $\bar{v} / \mathrm{A}$ were very small (Table I). Regression lines were fitted to the data by the method of least squares for warfarin concentrations ranging from 6 to $97 \mu$ moles per L. The lines for concentrations of 606 to $2,420 \mu$ moles per L were fitted by graphic means. Extrapolation of the regression lines yielded an apparent association constant of 154,000 at $3^{\circ} \mathrm{C}$ and 92 ,000 at $27^{\circ} \mathrm{C}$. The values of $\mathrm{n}, 0.87$ at $3^{\circ} \mathrm{C}$ and 0.99 at $27^{\circ} \mathrm{C}$, were rounded out to the nearest whole integer of 1 (13).

The reversibility of the interaction was evaluated at equilibrium by replacing the warfarincontaining buffer outside the bag with fresh buffer containing no warfarin. In all instances equilibrium was established at a lower concentration, indicating the reversible nature of the binding process. Because the experiments were carried out under equilibrium conditions and the interaction was reversible, the data could be evaluated by thermodynamic techniques. The standard free energy of binding $\left(\Delta F^{\circ}\right)$ for the first binding site was calculated for the four temperatures at which the interaction was studied. As shown in Table II, $\Delta \mathrm{F}^{\circ}$ ranged from $-6.54 \mathrm{kcal}$ per mole at $3^{\circ} \mathrm{C}$ to $-7.01 \mathrm{kcal}$ per mole at $37^{\circ} \mathrm{C}$. The standard enthalpy change $\left(\Delta \mathrm{H}^{\circ}\right)$ for the interaction, determined from a van't Hoff plot, was - $3.48 \mathrm{kcal}$ per mole, and the entropy change $(\Delta \mathrm{S})$ for the interaction was +11.2 entropy units. Thus, $53 \%$ of the $\Delta \mathrm{F}$ came from the favorable enthalpy change and $47 \%$ from the entropy change. To evaluate the binding sites of the albumin molecule for saturation, the average moles of warfarin bound per moles of albumin $(\bar{v})$ were plotted, both linearly and logarithmi-

TABLE II

Effect of changes in temperature on the binding of warfarin sodium by human plasma albumin

\begin{tabular}{rcccc}
\hline \hline Temperature & $\begin{array}{c}\text { Association } \\
\text { constant }\end{array}$ & $\begin{array}{c}\text { Log } 10 \\
\text { association } \\
\text { constant }\end{array}$ & $\Delta \mathrm{F}^{\circ *}$ \\
\hline${ }^{\circ} C$ & ${ }^{\circ} K$ & $L /$ mole & L/mole & kcal/mole \\
3 & 276 & 154,000 & 5.19 & -6.54 \\
15 & 288 & 140,000 & 5.15 & -6.73 \\
27 & 300 & 92,000 & 4.96 & -6.76 \\
37 & 310 & 87,000 & 4.94 & -7.01 \\
\hline
\end{tabular}

* Standard free energy of binding.

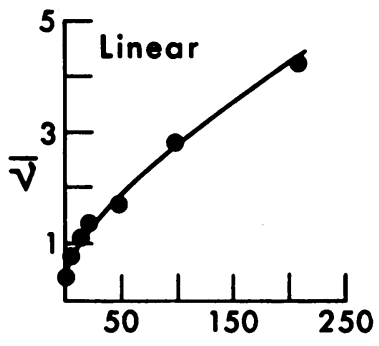

FREE [WARFARIN], $\mathrm{mg} / 1$

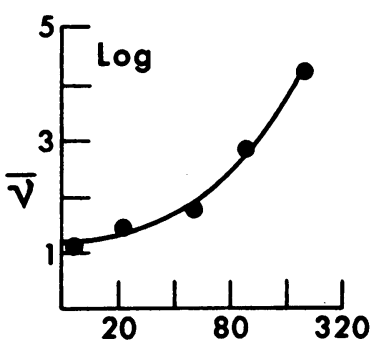

FREE [WARFARIN], $\mathrm{mg} / \mathrm{I}$

Fig. 6. EQUILIBRIUM diALYSIS STUdies : EFFECT OF THE CONCENTRATION OF WARFARIN ON THE AMOUNT BOUND. The molar ratio of bound warfarin and albumin $(\bar{\nu})$ is plotted as a function of the free warfarin concentration (top) and as a function of the $\log$ of the free warfarin concentration in the dialysis system (bottom).

cally, as a function of free warfarin at equilibrium (Figure 6). Neither plot of the data showed evidence of saturation (a plateau parallel to the abscissa); $\bar{\nu}$ continued to rise significantly at even the highest concentrations of free warfarin.

\section{Discussion}

The exclusive binding of warfarin sodium to the albumin fraction of the plasma proteins made it rational to study the interaction of the drug with pure albumin in an equilibrium dialysis system (14). The extensive aqueous solubility of warfarin sodium allowed its use in high concentrations and the achievement of large molar ratios of bound warfarin to albumin. With most pharmacologic and physiologic substances studied by equilibrium dialysis, there has been significant binding to the cellophone dialysis bags (15). In the present study correction for binding of warfarin to the dialysis bags was made by calculating the bag binding curve rather than by the less 
accurate direct comparison method (16). In analyzing the data we made no corrections for electrostatic interaction, since warfarin is a weak anion (17) and its only ionic structure is the enolate group (6). Such corrections were also omitted in other studies of albumin-anion interactions in which strong ionic groups were present, such as the sulfate group of methyl orange or azosulfathiazole (18).

No attempt was made to analyze the second or higher classes of binding sites present on the albumin molecule as these interactions occur only with concentrations of warfarin considerably higher than those found clinically (1), nor was a subtraction made for the influence of these binding sites, since it is possible that they contribute to binding even at the low concentrations of warfarin found clinically. Hence, the extrapolations to the $\bar{v} / \mathrm{A}$ axis of Figure 5 would represent the sum of all the association constants $(\mathrm{kn})$ present. The second or higher classes of binding sites contribute less than $5 \%$ to the total binding. Because saturation of albumin binding sites has never been experimentally observed with warfarin or any ligand, it may be meaningless to talk about specific classes of binding sites per se (8, 19). It would appear that the very act of complex formation with anions makes more sites available for further binding $(8,19)$.

The value for the apparent association constant was highest at the lowest temperature, $3^{\circ} \mathrm{C}$, and then showed a significant decrease with each increment in temperature. At $37^{\circ} \mathrm{C}$ the value was nearly half that at $3^{\circ} \mathrm{C}$. The decrease in the binding strength of albumin for warfarin with increasing temperature is characteristic of exothermic reactions (10). Similar decreases have been demonstrated with thyroxine (20), in hapten-antibody reactions (21), in insulin-antibody reactions (22), and with the penicillin derivatives methicillin and oxacillin (23). The free energy decrement for the interaction ranged between 6.5 and $7.0 \mathrm{kcal}$ per mole of warfarin. This magnitude of $-\Delta \mathrm{F}$ for an interaction with albumin was larger than that for most pharmacologic agents (24) or for peptide hydrogen bond formation (25) and was comparable to that of some antigen-antibody reactions (21). The negative sign for $\Delta \mathrm{F}^{\circ}$ means that the binding process under these conditions was spontaneous. $\Delta \mathrm{H}$ was also negative, signifying that the binding process was exothermic and that the strength of the association would decrease with an increase in temperature. The $\Delta \mathrm{S}$, or disorder factor of the thermodynamic changes, was positive, a finding reported for all albumin-anion interactions (21).

The surprising factor in the thermodynamic changes for the warfarin-albumin interaction was the large contribution to the $-\Delta \mathrm{F}$ by the negative $\Delta \mathrm{H}(53 \%)$. If the nature of the interaction were largely electrostatic, that is, if the anionic parts of the warfarin molecule combined with the cationic parts of the albumin molecule, the main source of the $-\Delta F$ would have been a large positive $\Delta \mathrm{S}$ with very little contribution from the $\Delta \mathrm{H}$ factor (19). Studies on the interaction between strongly ionized azo dyes and albumin have shown that the binding is mainly electrostatic and results chiefly from a large positive $\Delta \mathrm{S}(25)$. When the interaction of a weakly ionized azo dye (26) and an un-ionized azo dye (27) was studied, the contributions of $\Delta \mathrm{H}(53 \%)$ and $\Delta \mathrm{S}(47 \%)$ to the favorable $-\Delta \mathrm{F}$ in both studies were nearly equal, as was found in this study. These findings suggest that a significant portion of the binding energy of the warfarinalbumin interaction is derived from nonionic sources.

It can be postulated that at low values of $\bar{\nu}$ the interaction of albumin and warfarin sodium is mainly electrostatic and that the source of $-\Delta F$ is the positive $\Delta \mathrm{S}$ of solvent release (25). At higher concentrations of warfarin, the albumin binding sites may be formed by configurational change, in which unfolding of the peptide chains takes place with the breaking of hydrogen bonds (21). This process would be an endothermic reaction and would give rise to a positive $\Delta H$ (28). That a configurational change is important for albumin-anion binding has been shown by the markedly different magnitudes of $\Delta F$ for the stereoisomers of a ligand (21) and by direct evidence of configurational changes in the albumin molecule during the binding of azo dyes and detergents as measured by optical rotatory dispersion $(29,30)$. The last stages of the binding process could involve the close fitting of the albumin binding site to the warfarin molecule by means of hydrogen bonds (8). This reaction would give rise to a large negative $\Delta H$, as seen 
with the interaction of some haptens and their antibodies (31). The summation of all the processes would be a relatively small but positive $\Delta S$ and a large negative $\Delta H$. Although these interpretations are consistent with the data and with present theory, the thermodynamic changes could have been the result of interactions not yet known or could have occurred by a different sequence than stated above.

The exclusive binding of warfarin by albumin is not surprising since similarly complete binding by albumin has been established for most other drugs studied (14). The therapeutic action of a drug often depends on its effective concentration, as well as on its intrinsic activity (32). The effective concentration is the concentration of free drug, which for warfarin in human plasma and in 5\% human plasma albumin is less than $5 \%$ of the total warfarin present (33). Binding to plasma albumin probably affects the duration and intensity of a drug's action and protects the body against the full pharmacologic effect of the drug by temporarily inactivating it in a circulating reservoir that is in equilibrium with the unbound, active form of the drug $(7,32)$. If albumin binding did not occur, the unchanged drug would be cleared by glomerular filtration and by in vivo metabolism, and its pharmacologic effect would be shorter in duration (7). Thus, the primary effect of the warfarin-albumin interaction would be the confining of the drug molecules within the vascular space in an inactive form, thereby hindering their access to the sites of drug action, excretion, and metabolism (14). The strength of this binding process would explain why warfarin sodium does not enter red blood cells or cerebral spinal fluid, does not appear in the urine, and has a small volume of distribution that is identical to the albumin space (33). The long half-life of warfarin in plasma and the long biologic effect are consistent with such a strong interaction (1). However, it is possible that a limited rate of drug metabolism may contribute not insignificantly to the long half-life.

A very significant correlation exists between the binding by serum albumin of plant phenols that uncouple oxidative phosphorylation and their binding by hepatic mitochondrial protein (34). The coumarin anticoagulant drugs are plant phenols that uncouple oxidative phosphorylation, and their presumed site of action is the liver. Thus, the long biologic effect of warfarin may possibly be attributable to a long half-life of the drug in the environment of the mitochondria and a high degree of binding to mitochondrial protein.

\section{References}

1. O'Reilly, R. A., P. M. Aggeler, and L. S. Leong. Studies on the coumarin anticoagulant drugs: the pharmacodynamics of warfarin in man. J. Clin. Invest. 1963, 42, 1542.

2. Karler, A. Separations by continuous electrochromatography. Analyt. Chem. 1959, 31, 848.

3. O'Reilly, R. A., P. M. Aggeler, M. S. Hoag, and L. Leong. Studies on the coumarin anticoagulant drugs: the assay of warfarin and its biologic application. Thrombos. Diathes. haemorrh. (Stuttg.) 1962, 8, 82.

4. O'Reilly, R. A., and P. M. Aggeler. Coumarin anticoagulant drugs: hereditary resistance in man. Fed. Proc. 1965, 24, 1266.

5. O'Reilly, R. A., P. M. Aggeler, M. S. Hoag, L. S. Leong, and M. L. Kropatkin. Hereditary transmission of exceptional resistance to coumarin anticoagulant drugs: the first reported kindred. New Engl. J. Med. 1964, 271, 809.

6. Hiskey, C. F., and V. Melnitchenko. Clathrates of sodium warfarin. J. pharm. Sci. 1965, 54, 1298.

7. Scatchard, G. The attractions of proteins for small molecules and ions. Ann. N. Y. Acad. Sci. 1949, 51, 660 .

8. Karush, F. The interaction of optically isomeric dyes with bovine serum albumin. J. phys. Chem. 1952, 56, 70.

9. Klotz, I. M., and S. W. Luborsky. The binding of organic ions by proteins. Effects of changes in solvent and their implications as to the nature of the complexes. J. Amer. chem. Soc. 1959, 81, 5119.

10. Daniels, F., and R. A. Alberty. Physical Chemistry, 2nd ed. New York, John Wylie, 1961, p. 316.

11. Edsall, J. T. The molecular shapes of certain proteins and some of their interactions with other substances. Faraday Soc. Disc. 1953, 13, 9.

12. Baker, K. J., and S. E. Bradley. Binding of sulfobromophthalein (BSP) sodium by plasma albumin. Its role in hepatic BSP extraction. J. clin. Invest. $1966,45,281$.

13. Scatchard, G., J. S. Coleman, and A. L. Shen. Physical chemistry of protein solutions. VII. The binding of some small anions to serum albumin. J. Amer. chem. Soc. 1957, 79, 12.

14. Goldstein, A. The interactions of drugs and plasma proteins. Pharmacol. Rev. 1949, 1, 102.

15. Sterling, K. Molecular structure of thyroxine in relation to its binding by human serum albumin. J. clin. Invest. 1964, 43, 1721.

16. Hughes, T. R., and I. M. Klotz. Analysis of metalprotein complexes in Methods of Biochemical 
Analysis, D. Glick, Ed. New York, Interscience, 1956, vol. 3, p. 284.

17. Karush, F. Heterogeneity of the binding sites of bovine serum albumin. J. Amer. chem. Soc. 1950, 72, 2705

18. Klotz, I. M., R. K. Burkhard, and J. M. Urquhart. The binding of organic ions by proteins. Comparison of bovine and human serum albumins. J. phys. Chem. 1952, 56, 77.

19. Klotz, I. M., and J. Ayers. Protein interactions with organic molecules. Faraday Soc. Disc. 1953, 13, 189.

20. Sterling, K., P. Rosen, and M. Tabachnick. Equilibrium dialysis studies of the binding of thyroxine by human serum albumin. J. clin. Invest. 1962, 41, 1021.

21. Karush, F. The interaction of purified antibody with optically isomeric haptens. J. Amer. chem. Soc. 1956, 78, 5519.

22. Berson, S. A., and R. S. Yalow. Quantitative aspects of the reaction between insulin and insulinbinding antibody. J. clin. Invest. 1959, 38, 1996.

23. Scholtan, W. Bestimmungsmethoden und Gesetzmässigkeiten der Eiweissbindung von Sulfonamiden und Penicillinen. Antibiot. et Chemother. (Basel) 1964, 12, 103.

24. Meunier, M. T. Contribution à l'étude de la liaison de quelques médicaments aux protéines sériques. Ph.D. thesis, Université de Clermont-Ferrand, 1961.

25. Klotz, I. M. The nature of some ion-protein complexes. Cold Spr. Harb. Symp. quant. Biol. 1949, $14,97$.
26. Karush, F., and M. Sonenberg. Interaction of homologous alkyl sulfates with bovine serum albumin. J. Amer. chem. Soc. 1949, 71, 1369.

27. Klotz, I. M., and J. Ayers. Interactions of some neutral organic molecules with proteins. J. Amer. chem. Soc. 1952, 74, 6178.

28. Klotz, I. M., and J. M. Urquhart. The binding of organic ions by proteins. Effect of temperature. J. Amer. chem. Soc. 1949, 71, 847.

29. Markus, G., and F. Karush. Structural effects of anionic azo dyes on serum albumin. J. Amer. chem. Soc. 1958, 80, 89.

30. Markus, G., and F. Karush. Structural effects of the interaction of human serum albumin with sodium decyl sulfate. J. Amer. chem. Soc. 1957, 79, 3264.

31. Karush, F. The interaction of purified anti- $\beta$-lactoside antibody with haptens. J. Amer. chem. Soc. 1957, 79, 3380.

32. Brodie, B. B., and C. A. M. Hogben. Some physicochemical factors in drug action. J. Pharm. Pharmacol. 1957, 9, 345.

33. O'Reilly, R. A., P. M. Aggeler, and L. S. Leong. Studies on the coumarin anticoagulant drugs: a comparison of the pharmacodynamics of dicumarol and warfarin in man. Thrombos. Diathes. haemorrh. (Stuttg.) 1964, 11, 1.

34. Hansch, C., K. Kiehs, and G. L. Lawrence. The role of substituents in the hydrophobic bonding of phenols by serum and mitochondrial proteins. J. Amer. chem. Soc. 1965, 87, 5770. 